\title{
Nutritional value of field beans (Vicia faba L.) differing in antinutritive factors - rat assay
}

\section{Barbara Pastuszewska, Anna Ochtabińska and W. Grala}

The Kielanowski Institute of Animal Physiology and Nutrition. Polish Academy of Sciences, 05-110 Jablonna, Poland

(Received 27 July 1993; accepted 6 September 1993)

\begin{abstract}
In two balance experiments true protein digestibility (TD) and biological value (BV) of field bean (FB) varieties differing in tannin, trypsin inhibitor and lectin contents were studied on rats using whole (Expt. 1) and dehulled (Expt. 3) seeds. ADF and NDF digestibility and growth performance of rats fed on diets containing whole FB seeds was also assayed in Expt. 1 and 2, respectively. All diets were supplemented with $2.5 \mathrm{~g}$ DL methionine and $0.5 \mathrm{~g} \mathrm{~L}$-tryptophane per $16 \mathrm{~g} \mathrm{~N}$. TD was negatively corrclated with tannin contents $(r=-0.924, P \leqslant 0.01)$ while the correlation between $B V$ and tannins was positive but nonsignificant. TD and BV of protein of dehulled seeds were not affected either by trypsin inhibitor or lectin contents. Negative correlation between tannins and ADF digestibility was significant only when one variety was excluded from the calculations. The digestibility of NDF was not affected by tannins. Feed intake, growth rate, feed conversion and liver and pancreas weight of rats did not differ among groups fed diets containing whole $\mathrm{FB}$ seeds having different content of antinutrients.
\end{abstract}

KEY WORDS: field bean, antinutritive factors, protein value, rats

INTRODUCTION

Antinutritive factors (ANFs) present in field beans (Vicia faba) reduce the utilization of protein and energy in this crop when given to monogastric animals. The most frequent ANFs are: tannins, trypsin and chymotrypsin inhibitors, lectins and glucosides. However, condensed tannins present in the hull fraction in colour-flowered varieties are considered as the most deleterious antinutrient in field beans (FB) since they form complexes with dietary as well as enzymatic proteins and thus depress digestibility of nutrients (Marquardt, 1989; Gatel, 1992).

ISSN 1230-1388 (C) Institute of Animal Physiology and Nutrition 
The affinity of tannins to the different digestive enzymes is not equal and differences between the degree of inhibition of trypsin, alpha-amylase and lipase activity in rat and chicken intestine were observed (Horigome et al., 1988; Longstaff and McNab, 1991; Ahmed et al., 1991). According to Bourdon and Perez (1992) and Eggum et al. (1983) the digestibility of protein is affected by tannins to greater extent than digestibility of carbohydrates. An inhibitory effect of polyphenols has also been found on in vitro (Björck and Nyman, 1987; Griffiths, 1991) as well as on in vivo degradation of fibre in pigs (Hlodversson, 1987; Gdala, 1991; Jansman, 1993). The digestibility of dry matter (DM) and protein and the degradability of cellulose in ruminants (Garrido, 1992; Müller et al., 1989) is also influenced by polyphenols.

While a negative effect of FB tannins on protein digestibility is well documented, the effects of these compounds on utilization of absorbed protein (BV), digestion of fibre and on growth performance are not well established.

The objective of this study is to assess the effects of FB tannins on the digestibility of protein, and of acid- and neutral detergent fibre and on the biological value (BV) of protein. Furthermore the influence on growth performance and pancreas and liver weights was measured. The last part of the study included dehulled, tannin free FB and was aimed to evaluate the effects of lectin and trypsin inhibitors on protein digestibility and BV.

\section{MATERIALS AND METHODS}

Materials. Several varieties of FB with different tannin, trypsin inhibitor and lectin contents were used in the study. White- and coloured-flowering FB varieties of Polish (Martin and Kamir) and Dutch origin (Alfred, Toret, Caspar and Pistache) with tannin content varying from about 0.10 to $0.55 \%$ were used in all experiments while one Polish var. Tibo and one Dutch var. Baround were included additionally into experiment 3 .

Experimental design. Three experiments were performed. Experiment 1 and 2 were designed to evaluate the effect of tannin content in whole seeds on the following parameters: true digestibility (TD), biological value (BV) and net protein utilization (NPU), digestibility of ADF and NDF fractions (Expt. 1) and on the growth performance of rats (Expt. 2). In experiment 3 TD and BV of the same but dehulled $\mathrm{FB}$ varieties (without tannins) were compared. In addition two other varieties (whole and dehulled) were included.

Diets. The diets for protein evaluation and growth experiments contained FB seeds whole (Expt. 1 and 2) or dehulled manually (Expt. 3) as the only source of protein. Dietary protein (Nx 6.25 ) level was $9.5 \%$, which corresponds to a FB 
content from 30.6 to $44.0 \%$ of whole seeds and from 28.7 to $37.9 \%$ of dehulled seeds. The diets contained (in \%): minerals 3.0 ; vitamins 2.0 ; soya oil 4.0 ; sucrose 12.0 ; cellulose (only in diets used in Expt. 3) 3.0; and corn starch to 100.0. The diets for studying effect of tannins on digestibility of ADF and NDF contained $80.0 \% \mathrm{FB}$, which was the only source of fibre, minerals $3.0 \%$, vitamins $2.0 \%$ and sucrose to $100.0 \%$. All diets were supplemented with $2.5 \mathrm{~g} \mathrm{DL}-$ methionine and $0.5 \mathrm{~g} \mathrm{~L}$-tryptophane per $16 \mathrm{~g} \mathrm{~N}$.

Experimental procedure. TD and BV were determined by Thomas-Mitchell method on male rats from IFz:JAZ herd at the age of $30 \pm 1$ day with an initial mean body weight of $80 \mathrm{~g}$, seven rats per diet in experiment 1 and eight in experiment 3 . Feed intake was restricted to $11 \mathrm{~g} \mathrm{rat} /$ day in a 4 days preliminary period followed by 6 days of collection of faeces and urine. Endogenous and metabolic $\mathrm{N}$ was calculated as related to body weight according to Lehman's (1968) equations. NPU was calculated as TD $\times$ BV. At the end of the collection period in experiment 1 the animals were transferred to other diets containing the same FBs but at a dietary level of $80 \%$. After a 3 days preliminary period faeces were collected twice daily during 11 days, stored frozen, dried at $60{ }^{\circ} \mathrm{C}$ and analysed for ADF and NDF.

Growth experiment (Expt. 2) was performed during 21 days on $25 \pm 1$ day old male rats of an initial mean body weight of $56 \mathrm{~g}$, with seven animals per diet. The rats were maintained individually and fed to appetite. Feed intake and body weights were registered weekly and feed conversion efficiency (FCE) and protein efficiency ratio (PER) were calculated. At the end of the experiment the animals were killed and liver and pancreas weights were recorded.

Chemical analysis. $\mathrm{N}$ content in beans, diets, urine and faeces was determined by Kjeldahl method, ADF and NDF were analysed according to Van Soest on Fibertec $M$ (Tecator) apparatus. Condensed tannins were determined by the vanillin method according to Kuhla and Ebmeier (1981), trypsin activity according to modified Kakade method (van Oort et al., 1989) and lectins according to ELISA method (Hamer et al., 1989). All ANFs were determined in the whole seeds.

Statistical analysis. The results were subjected to analysis of variance using Statgraphic programme ver. 2.7. Correlations were calculated between dietary tannin content and TD and NPU of protein of whole seeds of six (Expt. 1) and eight (Expt. 1 and 3) varieties, BV of protein, and ADF and NDF digestibility of six varieties (Expt. 1). 


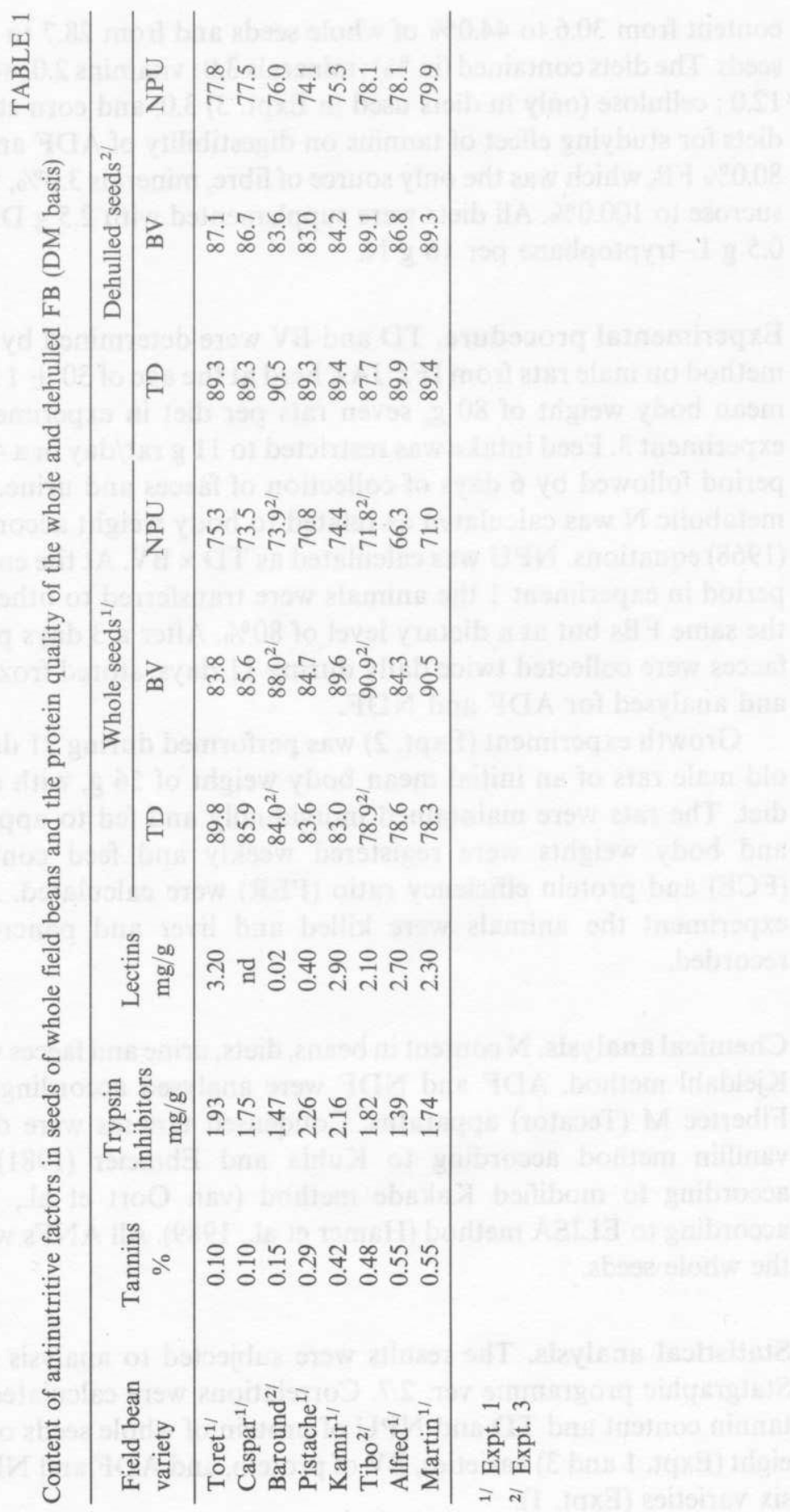




\section{RESULTS}

\section{ANFs content in field bean}

The content of main antinutritional substances in whole FB seed is given in Table 1 . The condensed tannins (TA) varied from $0.1 \%$ in low-tannin varieties Toret and Caspar to $0.55 \%$ in Alfred and Martin. Trypsin inhibitor content was within the range of 1.39 (var. Alfred) to $2.26 \mathrm{mg} / \mathrm{g}$ (var. Pistache), while lectins were very low in var. Baround and Pistache $(0.02$ and $0.40 \mathrm{mg} / \mathrm{g}$, respectively), but high in Toret $(3.20 \mathrm{mg} / \mathrm{g})$. There was no relationship between tannin, trypsin inhibitors and lectin contents.

Fibre contents were uniform and in the range from 11 to 12 and from 13 to $15 \% \mathrm{DM}$ for ADF and NDF, respectively (Table 3 ).

\section{Effect of ANFs on protein utilization}

The results of experiment 1 (Table 1) indicate substantial intervarietal differences in the parameters of protein utilization of whole FB seeds. Protein digestibility varied from about 78 in var. Martin with the highest tannin (TA) content to 90 in Toret lowest in TA, while the opposite situation was observed for BV (90.5 vs 83.8, respectively). Protein digestibility of 6 varieties in experiment 1 was inversely related to TA content in whole FB seeds (Table 2). When TD

TABLE 2 Correlation and regression coefficients between dietary tannin contents and parameters for protein quality and digestibility of fibre of field beans, respectively

\begin{tabular}{|c|c|c|c|c|}
\hline Item & & $\begin{array}{l}\text { Correlation } \\
\text { coefficient }\end{array}$ & Intercept & Slope \\
\hline TD & $\begin{array}{l}6 \text { varieties }^{1 /} \\
8 \text { varieties }^{2 i}\end{array}$ & $\begin{array}{l}-0.836^{*} \\
-0.924^{* *}\end{array}$ & $\begin{array}{l}87.64 \\
89.06\end{array}$ & $\begin{array}{l}-44.31 \\
-55.91\end{array}$ \\
\hline BV & 6 varieties $^{1 /}$ & 0.579 NS & & \\
\hline NPU & $\begin{array}{l}6 \text { varieties }^{1 /} \\
8 \text { varieties }^{2 i}\end{array}$ & $\begin{array}{l}-0.536 \mathrm{NS} \\
-0.714^{*}\end{array}$ & 75.57 & -30.69 \\
\hline NDF & $\begin{array}{l}\text { digestibility } \\
6 \text { varieties }^{1 /} \\
5 \text { varieties }^{3 /}\end{array}$ & $\begin{array}{l}-0.466 \mathrm{NS} \\
-0.572 \mathrm{NS}\end{array}$ & & \\
\hline $\mathrm{ADF}$ & $\begin{array}{l}\text { digestibility } \\
6 \text { varieties } \\
5 \text { varieties }^{3 i}\end{array}$ & $\begin{array}{l}-0.417 \mathrm{NS} \\
-0.934^{* *}\end{array}$ & 30.78 & -31.78 \\
\hline
\end{tabular}

1/ expt. 1

${ }^{2 /}$ expt. 1 and 3

3/ var. Toret excluded

* significant at $\mathrm{P} \leqslant 0.05$

** $\quad, \quad$ at $P \leqslant 0.01$ 
of whole seeds of two FBs evaluated in experiment 3 were included into calculations, the correlation coefficient increased. Eighty five percent of the variance in TD may be ascribed to the tannin content in FB. Dehulling had no influence on TD in the low-tannin Toret but increased TD from 3.4 units in Caspar to about 11 units in Alfred and Martin. Digestibility of protein of dehulled seeds was high and uniform and did not differ among varieties having different trypsin inhibitors (TI) and lectin contents (Table 1).

Biological value of whole FB supplemented with methionine and tryptophane was high (Table 1) and the correlation between TA content and BV of six varieties (Expt. 1) was not significant but was positive.

The utilization of digested protein (BV) may be subjected to between experimental variance (animals, season), therefore BV's of two varieties tested in Expt. 3 were not included into the correlation between TA and BV, calculated for six varieties tested in experiment 1 . Also the direct effect of dehulling of FB could not be estimated except for var. Tibo and Baround evaluated both as whole and dehulled seeds in the same experiment.

Dehulling resulted in lower BV's by 1.8 and 4.4 units in Tibo and Baround varieties, respectively. The differences between the BV's of six dehulled FBs were of similar range as in whole seeds and could not be related either to lectin or trypsin inhibitor contents.

Negative effects of tannins on NPU was smaller than on TD and was significant only when all varieties in experiments 1 and 2 were included in the calculations (Table 2).

\section{Effect of tannins on the digestibility of fibre}

Digestibility of both ADF and NDF was highest in Caspar $(0.1 \%$ TA) and lowest in Martin $(0.55 \%)$ (Table 3$)$. The correlation between dietary tannin content and digestibility of fibre was negative but statistically non significant

TABLE 3

Content and digestibility of fibre in ficld beans

\begin{tabular}{|c|c|c|c|c|c|}
\hline \multirow{2}{*}{$\begin{array}{l}\text { Field bean } \\
\text { variety }\end{array}$} & \multirow{2}{*}{$\begin{array}{c}\text { Tanin content } \\
\%\end{array}$} & \multicolumn{2}{|c|}{$\mathrm{ADF}$} & \multicolumn{2}{|c|}{ NDF } \\
\hline & & $\begin{array}{l}\text { content } \\
\% \text { DM }\end{array}$ & $\begin{array}{c}\text { digestibility } \\
\%\end{array}$ & $\begin{array}{l}\text { content } \\
\% \text { DM }\end{array}$ & $\begin{array}{c}\text { digestibility } \\
\%\end{array}$ \\
\hline Toret & 0.10 & 11.8 & $14.9^{\mathrm{ab}}$ & 13.7 & $34.1^{\mathrm{bc}}$ \\
\hline Caspar & 0.10 & 11.3 & $27.9^{\text {cde }}$ & 13.6 & $41.3^{\mathrm{d}}$ \\
\hline Pistache & 0.29 & 12.4 & $22.7^{\mathrm{bc}}$ & 15.1 & $30.5^{a b}$ \\
\hline Kamir & 0.42 & 12.1 & $22.8^{\text {bcd }}$ & 15.3 & $38.3^{\mathrm{cd}}$ \\
\hline Alfred & 0.55 & 12.2 & $17.5^{\mathrm{ab}}$ & 13.6 & $35.2^{\mathrm{bcd}}$ \\
\hline Martin & 0.55 & 11.6 & $14.4^{\mathrm{a}}$ & 15.2 & $26.8^{\mathrm{a}}$ \\
\hline
\end{tabular}

1/ Values with the same superscript within a column are not statistically different at $\mathrm{P}<0.05$ 
when calculated for six varieties (Table 2). When Toret was excluded from the calculations, the correlation coefficient between TA and ADF digestibility increased from -0.417 to $-0.934,(P \leqslant 0.01)$. The correlation between TA and NDF digestibility increased, but not significantly, from -0.466 to -0.572 when excluding the variety Toret.

\section{Effect of tannins on growth performance of rats}

The results of growth experiment (Expt. 2) did not reveal any effect of tannins on the measured parameters (Table 3). Differences in feed intake, growth rate and PER values among the varieties did not reach the level of statistical significance, only feed conversion efficiency differred on diets containing Martin and Alfred, both having similar contents of tannins, trypsin inhibitors and lectins. PER values varied from 3.08 to 3.40 and corresponded closely to NPU values, obtained in the balance experiment.

Relative liver and pancreas weights did not differ among the groups (Table 4).

TABLE 4

Results of the growth experiment

\begin{tabular}{lcccccc}
\hline $\begin{array}{l}\text { Field } \\
\text { bean } \\
\text { variety }\end{array}$ & $\begin{array}{c}\text { Feed } \\
\text { intake } \\
\mathrm{g}\end{array}$ & $\begin{array}{c}\text { Live } \\
\text { weight gain } \\
\mathrm{g}\end{array}$ & FCE & PER & $\begin{array}{c}\text { Liver } \\
\mathrm{g} / 100 \mathrm{~g} \\
\text { body } \\
\text { weight }\end{array}$ & $\begin{array}{c}\text { Pancreas } \\
\mathrm{g} / 100 \mathrm{~g} \\
\text { body } \\
\text { weight }\end{array}$ \\
\hline Toret & $280^{\mathrm{a}}$ & $89.1^{\mathrm{a}}$ & $3.15^{\mathrm{ab}}$ & $3.40^{\mathrm{a}}$ & $4.93^{\mathrm{a}}$ & $0.35^{\mathrm{a}}$ \\
Caspar & $288^{\mathrm{a}}$ & $96.4^{\mathrm{a}}$ & $3.01^{\mathrm{ab}}$ & $3.29^{\mathrm{a}}$ & $5.18^{\mathrm{a}}$ & $0.42^{\mathrm{a}}$ \\
Pistache & $274^{\mathrm{a}}$ & $83.3^{\mathrm{a}}$ & $3.35^{\mathrm{ab}}$ & $3.19^{\mathrm{a}}$ & $5.19^{\mathrm{a}}$ & $0.36^{\mathrm{a}}$ \\
Kamir & $292^{\mathrm{a}}$ & $95.0^{\mathrm{a}}$ & $3.09^{\mathrm{ab}}$ & $3.42^{\mathrm{a}}$ & $5.29^{\mathrm{a}}$ & $0.35^{\mathrm{a}}$ \\
Martin & $286^{\mathrm{a}}$ & $85.9^{\mathrm{a}}$ & $3.41^{\mathrm{b}}$ & $3.26^{\mathrm{a}}$ & $5.25^{\mathrm{a}}$ & $0.36^{\mathrm{a}}$ \\
Alfred & $316^{\mathrm{a}}$ & $107.4^{\mathrm{a}}$ & $2.90^{\mathrm{a}}$ & $3.08^{\mathrm{a}}$ & $4.95^{\mathrm{a}}$ & $0.38^{\mathrm{a}}$ \\
\hline
\end{tabular}

1 Values with the same superscript are not statistically different at $\mathrm{P}<0.05$

\section{DISCUSSION}

The results of the $\mathrm{N}$ balance experiments confirmed negative effects of $\mathrm{FB}$ tannins on protein digestibility as found in other studies (Bourdon and Perez, 1984; Lacassagne, 1988; Jansman, 1989). Besides forming complexes with dietary and enzymatic proteins, tannins cause in rats an increase of secretion of salivary proline-rich protein with a high affinity to tannins (Mehansho et al., 1987; Jansman, 1993). This may reduce their antinutritional effect but may also increase the excretion of endogenous nitrogen and in this way contribute to lower protein digestibility. The increase of endogenous $\mathrm{N}$ excretion is not accounted for in the calculations of TD. 
Utilization of absorbed protein was not negatively affected by FB tannins. On the contrary, a slight tendency was observed to lower BV's in low TA varieties (Toret, Caspar, Pistache and Baround) and higher BV's in high TA (Kamir, Tibo and Martin). An exception was var. Alfred. This finding does not corroborate the results of Eggum et al. (1983) who showed that polyphenols from tea and coffee depressed BV of soya bean meal and barley. The difference may be explained either by higher level of tannins in diets used by Eggum or by different nature of tea and coffee polyphenols. Jansman (1983) found significantly lower urinary $\mathrm{N}$ excretion and better utilization of digested $\mathrm{N}$ (apparent $\mathrm{BV}$ ) in pigs fed a diet containing 0.54 than one with $0.1 \%$ FB tannins.

True protein digestibility of dehulled seeds was almost this same in all varieties except for var. Tibo, which was 1.5 units less digestible. Therefore the increase in protein digestibility found in dehulled material can be considered as strictly related to removal of tannin.

Dehulling of FB does not affect the amount of other ANFs present in cotyledons and it may be assumed that the intervarietal differences in trypsin inhibitor and lectin contents in dehulled seeds were similar to those in whole seeds. High and very uniform digestibility of protein of dehulled seeds indicates that neither trypsin inhibitor (in the range from 1.39 to $2.26 \mathrm{mg} / \mathrm{g}$ ) nor lectins (from 0.02 to $3.20 \mathrm{mg} / \mathrm{g}$ of whole seeds) had any effect on digestion of FB protein by rats.

When feeding diets containing TI to rats and poultry the loss of endogenous protein rich in sulphur amimo acids will increase (Liener, 1989). This will affect BV when feeding diets deficient in methionine + cystine and has less infuence on digestibility. It was found in some experiments that inactivation of trypsin inhibitors by proper heating leads to an increase in BV while TD was unaffected (Pastuszewska, 1985).

Lectins will increase protein catabolism (Pusztai and Palmer, 1977; Pusztai, 1989) and thus cause greater urinary losses of nitrogen and lower BV's. In the present work BV of dehulled FB supplemented with the two most limiting amino acids was not affected by the trypsin inhibitor or lectin levels in the material. Differences in BV between dehulled Pistache (83.9) and Martin (89.3) and between Baround (83.6) and Tibo (89.1) probably may be ascribed to the content of the third limiting amino acid.

The results of the digestibility studies of acid and neutral detergent fibre are not conclusive. When var. Toret with low TA content is excluded, digestibility of ADF in five varieties follows TA pattern, which is not the case with NDF digestibility. It has been shown that polyphenols inhibit fibre degradation in vitro (Björck and Nyman, 1987; Griffiths, 1981) and also they have bacteriostatic effect in vivo, since they depress volatile fatty acid production in caecum of rats (Levrat et al., 1993). 
The effect of tannins on fibre fermentation may depend on the composition of fibre (Nyman and Björck, 1989) and also on the level of tannins and animal species. In pigs Hlodversson (1987), Gdala (1991) and Jansman (1993) have found that the digestibility of fibre was depressed by tannins present in legume seeds.

The nonsignificant effect of tannins on pancreas weight is in agreement with observation of Griffiths and Moseley (1980) in rats and Jansman (1993) using piglets. However, Ahmad et al. (1991) found an effect in chickens. Generally, rats and chickens - but not pigs - respond in a similar way to trypsin inhibitors with a heavier weight of pancreas. In our study the levels of trypsin inhibitor (1.39 to $2.26 \mathrm{mg} / \mathrm{kg}$ ) were probably too small to induce changes in pancreas weight.

\section{CONCLUSIONS}

The results of this study indicate that condensed tannins are the main antinutritional factors in FB causing reduced protein digestibility. However, the biological value of field bean protein was not influenced by TA. The levels of trypsin inhibitors and lectin in the material did not affect either protein digestibility or biological value of dehulled seeds. In spite of the negative influence on protein digestibility, tannins up to $0.55 \%$ had no effect on feed intake, growth rate, feed conversion or liver and pancreas weight of rats. A tendency to lower ADF but not NDF digestibility in FB varieties with higher tannin content was observed.

\section{REFERENCES}

Ahmed A. E., Smithard R., Ellis M., 1991. Activities of enzymes of the pancreas, and the lumen and mucosa of the small intestine in growing broiler cockerels fed on tannin-containing diets. $\mathrm{Br}$. $\mathrm{J}$. Nutr. 65,189197

Björck I., Nyman M., 1987. In vitro effects of phytic acid and polyphenols on starch digestion and fiber degradation. J. Food Sci. 52, 15881592

Bourdon D., Perez J. M., 1984. Valeur énergétique et azotée, pour le porc, de differents types de féverole pauvre ou riche en tannin. Journ. Rech. Porcine, France, 16, 401-408

Bourdon D., Perez J. M., 1992. Energy and protein values of faba beans (Vicia faba minor L.) for pigs: synthesis of French results. In: Proceedings of the Ist European Conference on Grain Legumes. Angers, pp. 521-524

Eggum B. O., Pedersen B., Jacobsen I., 1983. The influence of dietary tea, coffee and cocoa on protein and energy utilization of soya bean meal and barley in rats. Br. J. Nutr. 50, 197--205

Garrido A., Cabrera A., Gomez. A., Guerrero J. E., 1989. Relationship between tannin content and , in vitro" nutritive value in seeds of 24 strain in Vicia faba $\mathrm{L}$. In: Recent advances of research in antinutritional factors in legume seeds. J. Huisman, A. E. B. van der Poel and I. E. Liener (Editors). PUDOC, Wageningen, pp. 160-163

Gatel F., 1992. Protein quality of legume seeds for monogastric animals. In: Proceedings of the lst European Conference on Grain Legumes. Angers, pp. 461-473

Gdala J., 1981. Badania nad trawieniem skladników pokarmowych różnych grochów (Pisum sativum hortense i Pisum sarivum arvense) w przewodzie pokarmowym rosnących świń. Ph. D. Thesis, Mimeograph, The Kielanowski Institute of Animal Physiology and Nutrition, Jabłonna, pp. 107 
Griffiths D. W., 1981. The polyphenolic content and enzyme inhibitory activity of testes from bean and pea varieties. J. Sci. Food Agric. 31, 797-783

Griffiths D. W., Moseley G., 1980. The effect of diets containing field beans of high or low polyphenolic content on the activity of digestive enzymes in the intestine of rats. J. Sci. Food Agric. 30, 458-462

Hamer R. H., Koninkx J., van Oort M. G., Mouwen J., Huisman J., 1989. New developments in lectin analysis. In : Recent advances of research in antinutritional factors in legume seeds. J. Huisman, A. F. B. van der Poel and I. E. Liener (Editors). PUDOC, Wageningen, The Netherlands, pp. $30-33$

Hlodversson R, 1987. The nutritive value of white- and dark-flowered cultivars of pea for growing-finishing pigs. Anim. Feed Sci. Tech. 17, 245-255

Horigome T., Kumar R., Okamoto K.,1988. Effects of condensed tannins prepared from leaves of fodder plants on digestive enzymes in vitro and in the intestine of rats. Br. J. Nutr. 60 , $275-285$

Jansman A. J. M., 1993. Tannins in faba beans (Vicia faba L.) - antinutritional properties in monogastric animais. Ph. D. Thesis, Department of Animal Nutrition, Wageningen Agricultural University Wageningen, pp. 209

Kuhla S., Ebmeier C., 1981. Untersuchungen zum Tanningehalt in Ackerbohnen. Arch. Tierernähr. $31,573-588$

Lacassagne L., Francesch M., Carré B., Melcion J. P., 1988. Utilization of tannin-containing and tannin-free beans (Vicia faba) by young chicks: effects of pelieting feeds on energy, protein and starch digestibility. Anim. Feed Sci. Tech. 20, 59-68

Lehman H., Hock A., Bergner H., 1968. Bestimmung des N-Erhaltungsbedarfes von Albinoratten. Arch. Tierernähr. Berlin, 18, 280-291

Levrat M.-A., Texier O., Regerat F., Demigné C., Rémésy C., 1993. Comparison of the effects of condensed tannin and pectin on caecal fermentations and lipid metabolism in the rat.Nutr. Res. $13,427-433$

Liener I. E., 1989. Antinutritional factors in legume seeds: state of the art. ln: Recent advances of research in antinutritional factors in legume seeds. J. Huisman, A. F. B. van der Poel and I. E. Liener (Editors). PUDOC, Wageningen, pp. 6-13

Longstaff M., McNab J. M., 1991. The inhibitory effects of hull polysaccharides and tannins of field beans (Vicia faba L.) on the digestion of amino acids, starch and lipid and on digestive enzyme activities in young chicks. Br. J. Nutr. 65, 199-216

Marquardt R. R., 1989. Dietary effects of tannins, vicine and convicine. In: Recent advances of research in antinutritional factors in legume seeds. J. Huisman, A. F. B. van der Poel and I. E. Liener (Editors). PUDOC, Wageningen, pp. 141155

Mehansho H., Butler L. G., Carlson D. M., 1987. Dietary tannins and salivary prolin-rich proteins: Interaction, induction and defence mechanisms. Ann. Rev. Nutr. 7, 423-440

Müller H. M., Leinmüller E., Rittner U., 1989. Effect of tanninferous plant material on protein and carbohydrate degradation in rumen fluid in vitro. In: Recent advances of research in antinuritional factors in legume seeds. J. Huisman, A. F. B. van der Poel and I. E. Liener (Editors). PUDOC, Wageningen, pp. 156-159

Nyman M. E., Björck I. M., 1989. In vivo effects of phytic acid and polyphenols on the bioavailability of polysaccharides and other nutrients. J. Food Sci. 54, 1332-1335

Pastuszewska B., 1985. Czynniki wpływające na wartość pokarmową bobiku, grochu i lubinu dla zwierząt nieprzeżuwających. Ossolineum, Wrocław, pp. 140

Pastuszewska B., Smulikowska S., Chibowska M., Janowska G., 1992. Effect of dehulling and heat treatment on protein and energy value of field bean. In: Proceedings of the lst European Conference on Grain Legumes. Angers, pp. 475-476

Pusztai A., Palmer R., 1987. Nutritional evaluation of kidney beans (Phaseolus vulgaris); the toxic principle. J. Sci. Food Agric. 28, 620-623

Van Oort M. G., Hamer R. J., Slaager A. E., 1989. The trypsin inhibitor assay: improvement of existing method. In: Recent advances of research in antinutritional factors in legume seeds. J. Huisman, A. F. B. van der Poel and I. E. Liener (Editors). PUDOC, Wageningen, pp. 110-113 


\section{STRESZCZENIE}

Wartość pokarmowa nasion bobiku o różnej zawartości czynników antyodżywczych oznaczana w testach na szczurach

Na szczurach przeprowadzono dwa doświadczenia bilansowe, w których oznaczono strawność (TD) i wartość biologiczną (BV) białka calych (dośw. 1) i obłuszczonych (dośw. 3) nasion bobiku odmian o różnej zawartości tanin, inhibitora trypsyny i lcktyn. Oznaczono ponadto strawność frakcji wlókna ADF i NDF (dośw. 1), spożycie paszy, tempo wzrostu i wykorzystanie paszy oraz masę wątroby $i$ trzustki szczurów żywionych dietami zawierającymi całe nasiona bobiku jako jedyne źródło białka (dośw. 2). Diety były uzupelnione metioniną i tryptofanem w ilości odpowiednio: 2,5 i $0,5 \mathrm{~g} / 16 \mathrm{gN}$. Strawność białka była ujemnie skorelowana $\mathrm{z}$ zawartością $\operatorname{tanin}(\mathrm{r}=-0,924: \mathrm{P} \leqslant 0,01)$, natomiast korelacja między wartością biologiczną a taninami była dodatnia, lecz statystycznie nieistotna. TD i BV białka obluszczonych nasion odmian zawierających inhibitor trypsyny w ilości od 1,39 do $2,26 \mathrm{mg} / \mathrm{SM}$ i lektyn od 0,02 do $3,20 \mathrm{mg} / \mathrm{gM}$ nie różniła się istotnie. Tendencja do niższej strawności ADF nasion o wyższej zawartości tanin została potwierdzona statystycznie po wyeliminowaniu z obliczeń odmiany Toret, zaś strawność NDF nie zależała istotnie od ilości tanin. Wyniki doświadczenia wzrostowego wskazują na brak wpływu tanin i pozostałych czynników antyodżywczych bobiku na oznaczane wskaźniki. 